\title{
Influence of chronic carbon disulphide intoxication on the development of experimental atherosclerosis in rats*
}

\author{
TERESA WROŃSKA-NOFER, S SZENDZIKOWSKI, AND \\ MARIA OBREBSKA-PARKE $\dagger$
}

From the Departments of Biochemistry and Pathomorphology, Institute of Occupational Medicine, PO Box 199, 90-950 Lodz, Poland

ABSTRACT Rats fed on atherogenic diets containing $2 \%$ cholesterol and $0.5 \%$ cholic acid with or without $0.15 \%$ thiouracil were exposed to carbon disulphide $\left(\mathrm{CS}_{2}\right)$ vapours $(1 \mathrm{mg} / \mathrm{l}$ of air $)$, five hours a day, six days a week for 6-10 months. Serum and aorta lipid contents were determined, and the extent of atherosclerotic changes was investigated. The following effects of chronic exposure to $\mathrm{CS}_{2}$ were found: (1) slower gain in body weight when rats were fed on atherogenic diet; (2) greater increase in serum cholesterol content (after thiouracil supplemented diet); (3) moderate increase in total cholesterol content in the aorta wall with a significantly increased esterified cholesterol fraction but none in phospholipid level in this tissue; and (4) more advanced lipid infiltrates of coronary arteries and endocardium, the latter predominantly in the aortic valves. These results together with data from previous studies indicate that metabolism of arterial lipids participates in the process of artheroma formation after chronic exposure to $\mathrm{CS}_{2}$ vapours.

There is a considerable amount of evidence on carbon disulphide induced vasculopathy including increases of lipid infiltration in arterial walls, ${ }^{1-11}$ but the nature of $\mathrm{CS}_{2}$-induced changes in lipid metabolism is still far from clear. The extensive biochemical studies carried out in this laboratory on rats chronically exposed to $\mathrm{CS}_{2}$ have shown an increased rate of liver cholesterol synthesis ${ }^{12-15}$ and a parallel decrease of liver cholesterol degradation, ${ }^{16}$ an impaired plasma lipolytic activity ${ }^{17} 18$ with resulting raised plasma lipid concentrations, ${ }^{13-15} 19$ disturbance of lipid metabolism in the aortic tissue including decreased lipolytic activity, 1820 and an increased rate of ${ }^{14} \mathrm{C}$-cholesterol influx from serum and a raised rate of cholesterol synthesis ${ }^{21}$ in the aorta wall.

Despite these profound disturbances in the lipid metabolism of rats chronically exposed to $\mathrm{CS}_{2}$, the histopathological signs of atherosclerosis were not seen during the above investigations (unpublished observations). We have assumed, therefore, that the

*This investigation has been carried out partly under the Polish-American Agreement No 05-008-2 with the Occupational Health Program, US Public Health Service.

$\dagger$ Present address: Department of Biochemistry, University of Surrey, Guildford, England.

Received 22 January 1979

Accepted 17 May 1980 initial metabolic disturbances caused by $\mathrm{CS}_{2}$ precede the morphological arterial changes that may develop eventually after long-term exposure to $\mathbf{C S}_{2}$ in suitable experimental conditions. The present work has been undertaken to evaluate the effect of $\mathrm{CS}_{2}$ alone or in combination with hyperlipaemic diets on the development of biochemical and morphological changes in the arterial wall of rats exposed to $\mathrm{CS}_{2}$.

\section{Material and methods}

Eighty-four female Wistar albino rats $(180 \mathrm{~g}$ initial body weight) were divided into groups according to their diets and the duration of $\mathbf{C S}_{2}$ exposure:

I 1 standard chow*/basal diet/-non-exposed controls (BD)

2 standard chow and $\mathrm{CS}_{2}$ exposure for 12 to 15 months $\left(\mathrm{BD}+\mathrm{CS}_{2}\right)$

II 1 atherogenic diet-1-non-exposed controls (AD-1)

2 atherogenic diet-1 and $\mathrm{CS}_{2}$ exposure for 10 months (AD-1 + $\mathrm{CS}_{2}$ )

III 1 atherogenic diet-2-non-exposed controls (AD-2)

2 atherogenic diet-2 and $\mathrm{CS}_{2}$ exposure for 6 months (AD-2 $+\mathrm{CS}_{2}$ ).

*Laboratory chow for rats manufactured by LSM-Lowicz. 
Rats were exposed to $\mathrm{CS}_{2}$ in the inhalation chambers at a concentration of $1 \mathrm{mg} \mathrm{CS} / \mathrm{l}$ of air for five hours daily six days a week. Both atherogenic diets consisted of ground wheat meal $48 \%$, casein $25 \%$, arachid oil $22 \%$, salt mixture $4 \%$, ${ }^{*}$ and vitamins $1 \% \dagger$ supplemented (at the expense of wheat) with: cholesterol $2 \%$, cholic acid $0.5 \%$, and choline chloride $0.25 \%$. AD-1 was supplemented with $2 \%$ cholesterol only, AD-2 with $2 \%$ cholesterol and $0.15 \%$ thiouracil. The daily intake of diet in control and $\mathrm{CS}_{2}$ intoxicated rats was maintained on uniform levels. Water was allowed ad libitum. The body weight of all rats was recorded once a month.

\section{Biochemical investigations}

Blood samples were collected from the tail vein and the following determinations were carried out: total cholesterol, ${ }^{22}$ triglycerides, ${ }^{23}$ phospholipids, ${ }^{24}$ and free fatty acids. ${ }^{25}$ At the end of the experiment the animals were decapitated and aortas were removed for determination of lipid content. Total lipids were extracted from the homogenate using the method of Folch et al. $^{26}$ Individual classes of lipids separated by thin-layer chromatography were subsequently visualised with iodine vapour and extracted for chemical assay (DE Bowyer and J EKing, unpublished observations). The procedure of Babson et $a^{27}$ was used for free and esterified cholesterol determination; phospholipids were estimated by Usher's method. ${ }^{24}$

\section{Histological investigations}

All hearts and additional small segments of aorta from two rats selected at random from each group were excised and fixed in formol-calcium immediately after death. Lipid staining in tissue blocks using isopropanol solution of Fat Red 7B was used (S Szendzikowski and $\mathrm{T}$ Wrońska, unpublished observations). The whole heart and specimens of aorta were impregnated with the dye solution and serial frozen sections were cut. Several of the sections were counterstained with Mayer's haematoxyline. After screening, selected sections were restained with haematoxyline and eosine, Lillie and Fulmer's elastic tissue stain, or Astra Blue for acid mucopolysaccharides. About 100 sections of each heart were examined in routine and polarised light.

*NaCl-70; $\mathrm{CaHPO}_{4}, 2 \mathrm{H}_{2} \mathrm{O}-410$; potassium citrate, $\mathrm{H}_{2} \mathrm{O}-423$; $\mathrm{MgSO}_{4}, 7 \mathrm{H}_{2} \mathrm{O}-95$; ferric citrate-15; KI-6.5; NaF-5.5; $\mathrm{MnSO}_{4}$, $5 \mathrm{H}_{2} \mathrm{O}-1 \cdot 7 ; \mathrm{CuI}_{2}-0.5 ; \mathrm{AlK}\left(\mathrm{SO}_{4}\right)_{2}, 12 \mathrm{H}_{2} \mathrm{O}-0.92 ; \mathrm{ZnSO}_{4}, 7 \mathrm{H}_{2} \mathrm{O}-$ 0.50 (in grams).

+Vitamin $B_{1}-0 \cdot 12$; vitamin $B_{2}-0 \cdot 40$; inositol-8; vitamin $B_{6}$ 0.08 ; calcium panthothenate- 2.40 ; nicotinic acid-8; paminobenzoic acid-24; biotin-0.008; folic acid- 0.08 ; vitamin $\mathrm{B}_{12}-0.002$; choline-24 (in grams); potato starch-up to $1000 \mathrm{~g}$, that is, $932.91 \mathrm{~g}$.

\section{Results}

\section{BODY WEIGHT}

There were no differences in the body weights of the rats exposed to $\mathrm{CS}_{2}$ and the non-exposed controls fed the basal diet. Rats exposed to $\mathrm{CS}_{\mathbf{2}}$ and control rats maintained on diet $\mathrm{AD}-1$ gained $20 \%$ and $40 \%$ of their original body weight respectively. Loss of body weight observed in rats fed on diet AD-2 amounted to $15 \%$ in controls and $20 \%$ after six months of exposure to $\mathrm{CS}_{2}$.

\section{BLOOD LIPIDS}

After 15 months of $\mathrm{CS}_{2}$ intoxication a pronounced increase of cholesterol-total and esterified-was observed in the serum of rats fed on the basal diet (table 1). Both atherogenic diets had induced a noticeable increase in serum cholesterol content by the end of the first month's feeding. During the first six months of exposure no significant effect of $\mathrm{CS}_{2}$ on the cholesterol content was found. At the end of the experiment effects of diets AD-1 and AD-2 were slightly intensified by $\mathrm{CS}_{2}$ intoxication (tables 2 and 3).

\section{AORTA LIPIDS}

After feeding animals on diets AD-1 and AD-2 for ten and six months respectively, the concentrations of total cholesterol and cholesterol esters increased, but not to the same extent. Esterified cholesterol showed the most pronounced increase (by $174-374 \%$ in AD-1 and AD-2 groups respectively as compared to control rats fed on the basal diet-table 4). The 6-10 months of feeding on either atherogenic diet increased the content of total cholesterol by $10-38 \%$ compared with the controls. The increase in both total and esterified cholesterol induced by these diets was intensified by $\mathrm{CS}_{2}$ (table 4).

In rats kept on basal diet a moderate enhancement of total cholesterol and a pronounced increase of cholesterol esters was noted after exposures of 12 and 15 months (table 4). In all groups of rats exposed

Table 1 Content of cholesterol in serum of control and $\mathrm{CS}_{2}$-exposed rats fed on basal diet.* (Number of animals in parentheses)

\begin{tabular}{|c|c|c|}
\hline \multirow[t]{2}{*}{ Group } & \multicolumn{2}{|c|}{ Cholesterol $(\mathrm{mg} / 100 \mathrm{ml})$} \\
\hline & Total & Esters \\
\hline $\begin{array}{l}\text { Control } \\
\mathrm{CS}_{2}\end{array}$ & $\begin{array}{c}54 \cdot 4 \pm 12 \cdot 5 \\
(7) \\
78 \cdot 3 \stackrel{ \pm}{ \pm} 24 \dagger \\
(7)\end{array}$ & $\begin{array}{c}36 \cdot 7 \pm 9 \cdot 5 \\
(8) \\
58 \cdot 1 \underset{(8)}{ \pm} 20.5 \dagger\end{array}$ \\
\hline
\end{tabular}

* Content of cholesterol in serum was determined after 15 months of exposure to $\mathrm{CS}_{2}$ at conc $1.0 \mathrm{mg} / \mathrm{l}$. Mean values $\pm \mathrm{SD}$ are given. †Statistically significant from controls, $p<0.05$. 
Table 2 Concentration of lipids in serum of rats exposed to $C S_{2}$ and fed atherogenic diet-1 $(A D-1)^{*}$

\begin{tabular}{|c|c|c|c|c|c|c|}
\hline \multirow{2}{*}{$\begin{array}{l}\text { Time of } \\
\text { exposure } \\
\text { (months) }\end{array}$} & \multirow[t]{2}{*}{ Group of animals } & \multicolumn{2}{|c|}{ Cholesterol $(\mathrm{mg} / 100 \mathrm{ml})$} & \multirow{2}{*}{$\begin{array}{l}\text { Phospholipids } \\
(\mathrm{mg} / 100 \mathrm{ml})\end{array}$} & \multirow{2}{*}{$\begin{array}{l}\text { Triglycerides } \\
(\mathrm{mg} / 100 \mathrm{ml})\end{array}$} & \multirow{2}{*}{$\begin{array}{l}\text { Free fatty acids } \\
(m E q / l)\end{array}$} \\
\hline & & Total & Esters & & & \\
\hline 1 & $\mathrm{CS}_{2}+\mathrm{AD}-1$ & $277 \cdot 3 \pm 71 \cdot 6$ & $236.4 \pm 55 \cdot 8$ & $124 \cdot 3 \pm 30 \cdot 5$ & 一 & $\rightarrow$ \\
\hline \multirow[t]{2}{*}{3} & $C+A D-1$ & $345.9 \pm 85.5$ & $286.0 \pm 91.7$ & $99 \cdot 0 \pm 31 \cdot 7$ & $86.6 \pm 9$ & $0.6 \pm 0.17$ \\
\hline & $\mathrm{CS}_{2}+\mathrm{AD}-1$ & $333.9 \pm 113.7$ & $295 \cdot 4 \pm 91 \cdot 7$ & $98 \cdot 0 \pm 21 \cdot 5$ & $83 \cdot 3 \pm 20.5$ & $0.4 \pm 0.17$ \\
\hline 6 & $\mathrm{C}+\mathrm{AD} 1$ & $360.0 \pm 70.6$ & $299 \cdot 6 \pm 54 \cdot 7$ & $198 \cdot 0 \pm 21 \cdot 7$ & - & $0.27 \pm 0.04$ \\
\hline \multirow[t]{2}{*}{10} & $C+A D-1$ & $366.4 \pm 75.7$ & $301 \cdot 1 \pm 65 \cdot 4$ & $230.7 \pm 23.3$ & $56 \cdot 0 \pm 15 \cdot 7$ & $0.75 \pm 0.16$ \\
\hline & $\mathrm{CS}_{2}+\mathrm{AD}-1$ & $404.6 \pm 98.9$ & $331 \cdot 0 \pm 80 \cdot 1$ & $190 \cdot 2 \pm 32 \cdot 2$ & $78.4 \pm 16.1 \dagger$ & $0.72 \pm 0.2$ \\
\hline
\end{tabular}

* Each value is the mean $\pm \mathrm{SD}, \mathrm{n}=12$.

+Statistically significant from controls, $\mathrm{p}<0.05$.

Table 3 Concentration of lipids in serum of rats exposed to $C S_{2}$ and fed atherogenic diet-2 (AD-2)*

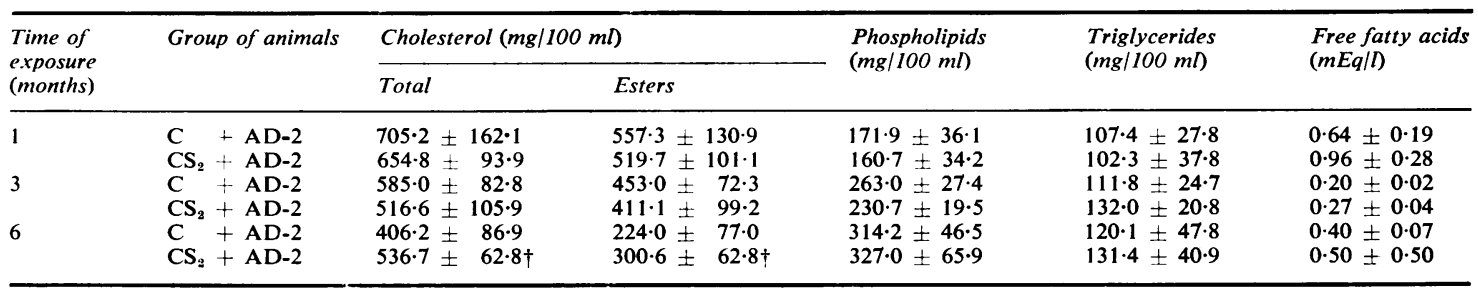

*Each value is mean $\pm S D, n=12$.

+Statistically significant from controls, $\mathrm{p}<0.05$.

Table 4 Effects of $\mathrm{CS}_{2}$ exposure and atherogenic diets on cholesterol content in the aortic wall of rats

\begin{tabular}{|c|c|c|c|c|c|}
\hline \multirow[t]{2}{*}{ Type of diet } & \multirow[t]{2}{*}{ Group } & \multirow{2}{*}{$\begin{array}{l}\text { Duration of } \\
\text { exposure (months) }\end{array}$} & \multicolumn{2}{|l|}{ Cholesterol } & \multirow{2}{*}{$\begin{array}{l}\text { Phospholipids } \\
\text { (mg/g wet tissue) }\end{array}$} \\
\hline & & & $\begin{array}{l}\text { Esters } \\
(\mathrm{mg} / \mathrm{g} \text { wt tissue })\end{array}$ & Total & \\
\hline \multirow[t]{2}{*}{ Basal diet } & Control & 一 & $0 \cdot 11$ & 1.9 & - \\
\hline & $\mathrm{CS}_{2}$ & 12 & $0 \cdot 17$ & $2 \cdot 1$ & - \\
\hline \multirow[t]{2}{*}{ Basal diet } & Control & - & $0 \cdot 19$ & $2 \cdot 1$ & $5 \cdot 4$ \\
\hline & $\mathrm{CS}_{2}$ & 15 & 0.44 & $2 \cdot 6$ & $5 \cdot 5$ \\
\hline & $\mathrm{CS}_{2}$ & 10 & 0.84 & $3 \cdot 4$ & $6 \cdot 4$ \\
\hline \multirow[t]{2}{*}{ Atherogenic diet-2 } & Control & - & 0.9 & $2 \cdot 34$ & $7 \cdot 4$ \\
\hline & $\mathrm{CS}_{z}$ & 6 & $1 \cdot 4$ & $3 \cdot 4$ & $7 \cdot 7$ \\
\hline
\end{tabular}

Figures for cholesterol represent mean value for pooled aortas in each group (9-12 rats per group).

to $\mathrm{CS}_{2}$ the relative contribution of the esterified fraction in the total cholesterol was greatly increased. No substantial changes in the concentration of aortic phospholipids were found in all groups of rats under investigation (table 4).

\section{MORPHOLOGICAL INVESTIGATIONS}

No lipid deposits were seen in the aorta, pulmonary artery, coronary vessels, and endocardium of control rats fed on basal diet. Occasional slight increases in the thickness of the walls of some coronary arterial branches within the muscle of the left cardiac ventricle was the only abnormal finding (fig 1). In the corresponding experimental group killed after 15 months of $\mathrm{CS}_{2}$ exposure similar changes were more often noted, with the occasional positive Fat Red staining indicating deposition of lipids (fig 2).

No signs of gross atheromas were found in the aortas and hearts of rats fed on atherogenic diets. Microscopic lesions in the form of extra or intracellular, or both, lipid deposits were present in the endocardium of the valves of the heart, but ascending most prominently in the aortic valves, in the intima and inner media of the aorta, and in the intima and media of the coronary arteries. With a few exceptions changes in the coronary arteries were limited to the intramural arterial branches within the left ventricular wall and the papillary muscles. Aortic intima 
Table 5 Combined grade of lipid deposits in coronary arteries, initial portion of aorta, and valvular endocardium in rats fed on atherogenic diets $(A D-1, A D-2)$ and exposed to $C S_{2}$

\begin{tabular}{|c|c|c|c|c|c|c|c|c|c|c|c|}
\hline \multirow[t]{2}{*}{ Diet } & \multirow{2}{*}{$\begin{array}{l}\text { Duration of exposure } \\
\text { (months) }\end{array}$} & \multicolumn{5}{|c|}{ Control } & \multicolumn{5}{|c|}{$C S_{2}$} \\
\hline & & $0^{\circ}$ & $I^{\circ}$ & $I I^{\circ}$ & $I I I^{\circ}$ & $I V^{0}$ & $O^{\circ}$ & $I^{\circ}$ & $I^{\circ}$ & $H I$ & $I V$ \\
\hline Atherogenic I & 10 & 0 & 2 & 3 & 5 & 0 & 0 & 0 & 1 & 9 & 0 \\
\hline Atherogenic II & 6 & 0 & 3 & 2 & 1 & 2 & 0 & 0 & 1 & 2 & 5 \\
\hline Total & & 0 & 5 & 5 & 6 & 2 & 0 & 0 & 2 & 11 & 5 \\
\hline
\end{tabular}

$0^{\circ} \quad$ No discernible lipid deposits.

$I^{\circ} \quad$ Minute lipid deposits either in initial portion of aorta and in valvular endocardium or in coronary arteries.

II $^{\circ}$ Small lipid deposits in coronary arteries, initial aortas, and valves; alternatively more advanced endocardial and aortic lesions while no lipid deposits in coronary vessels recorded.

III $^{\circ}$ Moderate lipid deposits in coronary arteries, initial aortas, and valves.

IV ${ }^{\circ}$ Advanced atheromas of coronary vessels with regional narrowing; large lipid deposits in initial aortas and valves.

distant from the initial portion occasionally contained scattered, minute lipid deposits.

Extensive deposits of lipids were seen in the coronary arteries, ascending aorta, and the cardiac valves in animals fed on diet AD-2 at the sixth month of the experiment (figs 3 and 4). Prolonged feeding with the diet AD-1 (10 months' duration) resulted in advanced coronary lesions (fig 5) with a moderate grade of aortic and valvular involvement. In rats maintained on diet $\mathrm{AD}-2$ and exposed to $\mathrm{CS}_{2}$ small deposits of crystalline cholesterol were found occasionally within the coronary atheromas

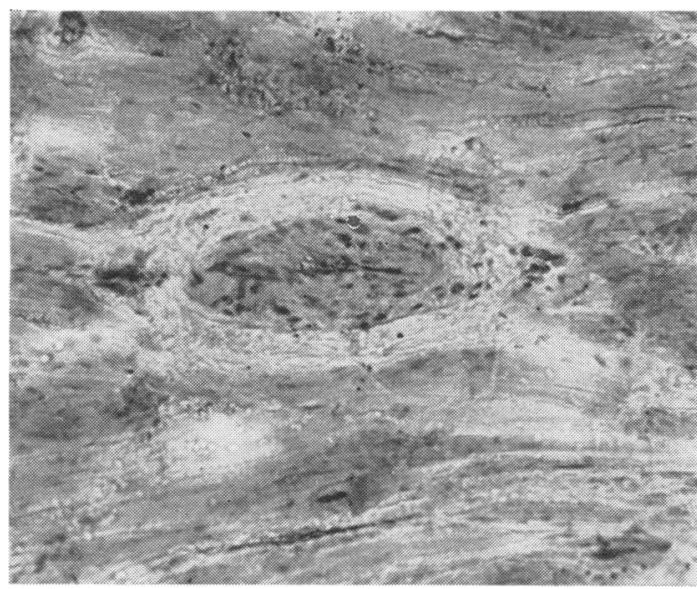

Fig 1 Branch of coronary artery within muscle of left cardiac ventricle of a control rat fed standard diet $(15$ months old). Slight thickening of vessel's wall; no accumulation of lipids. (Fat Red $7 B$ and haematoxylin; magn $\times 300$.) (fig 6). They were accompanied by focal hyaline formation and minute calcium deposits in these lesions. Table 5 shows the results of comparative grading of lesions recorded in animals maintained on atherogenic diets, which indicate a distinct shift toward higher grades of abnormalities in the animals exposed to $\mathrm{CS}_{2}$.

The frequencies of lipid deposits of grades $\mathrm{III}^{\circ}$ and $\mathrm{IV}^{\circ}$ against the grades $0^{\circ}-\mathrm{II}^{\circ}$ in the exposed and nonexposed groups of rats fed on atherogenic diets were compared using the Fisher exact probability test. The difference is statistically significant $(p=0.05$.

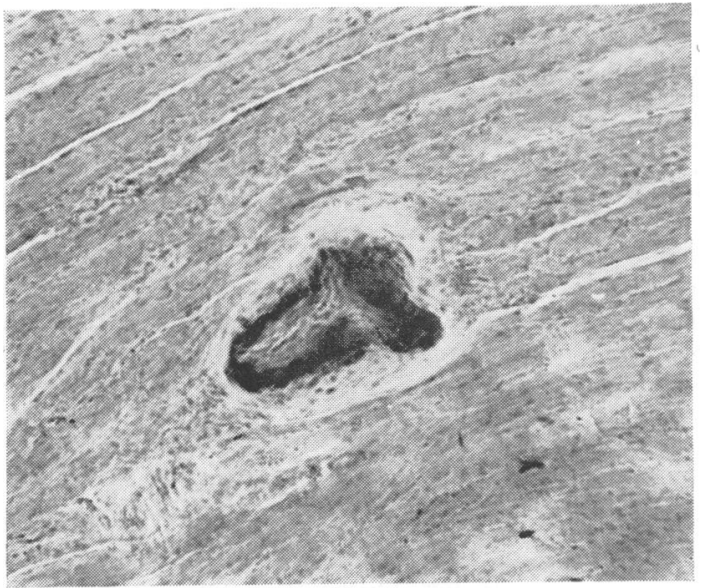

Fig 2 Branch of coronary artery within muscle of left cardiac ventricle of a rat fed standard diet, exposed to $C S_{2}(1.0 \mathrm{mg} / \mathrm{l})$ over 15 months. Unevenly thickened wall of vessel contains accumulated lipids. (Fat Red $7 B$ stain and haematoxylin; magn $\times 300$.) 


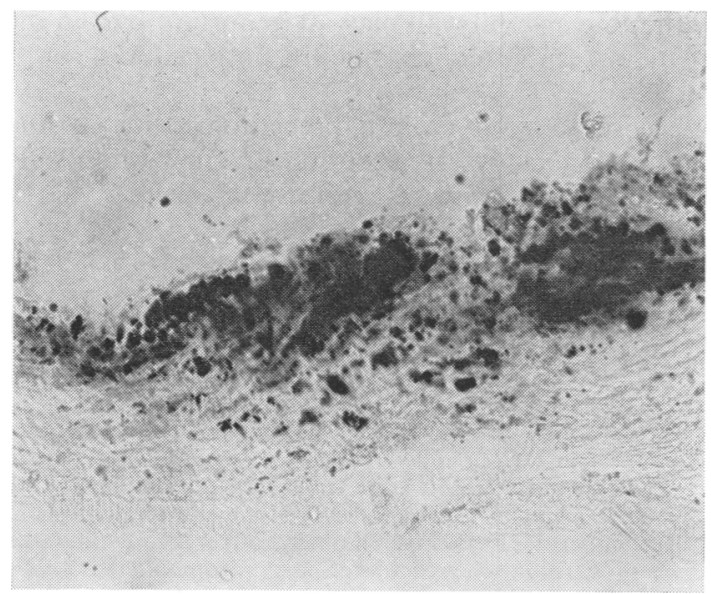

Fig 3 Lipids deposited in wall of initial aorta of rat maintained for six months on atherogenic diet $(A D-2)$ and exposed to $C S_{2}$. (Fat Red 7B; magn $\times 300$.)

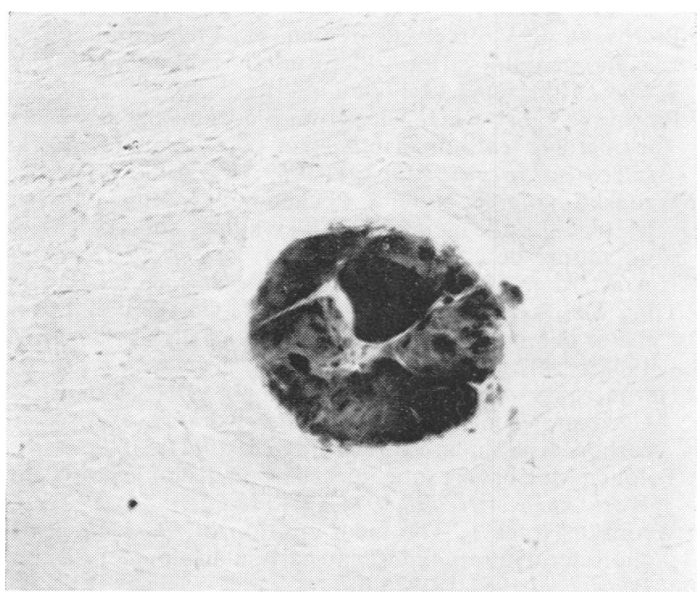

Fig 4 Coronary artery within left ventricular wall after six months on atherogenic diet $(A D-2)$ and $C S_{2}$ exposure. Accumulation of fat in thickened intimal and medial layer with pronounced reduction of vascular lumen. (Fat Red $7 B ;$ magn $\times 300$.)

\section{Discussion}

In the present investigation there was a lack of any obvious gross and histological lesions within the aorta of the non-hypercholesterolaemic $\mathrm{CS}_{2}$ intoxicated rats consistent with previous findings. Furthermore, it has been shown (as a confirmation and extension of previous observations) that chronic exposure to $\mathrm{CS}_{2}$ may produce lipid metabolic dis-

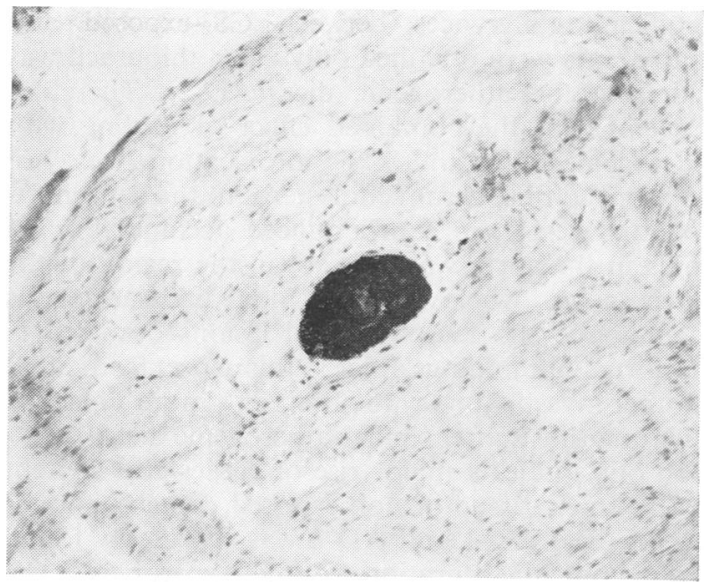

Fig 5 Coronary artery within papillary muscle of left cardiac ventricle after 10 months of feeding on atherogenic diet $(A D-I)$ and $C S_{2}$ exposure. Large deposit of fat, narrowing of vascular lumen. (Fat Red 7B stain and haematoxylin; magn $\times 150$.)

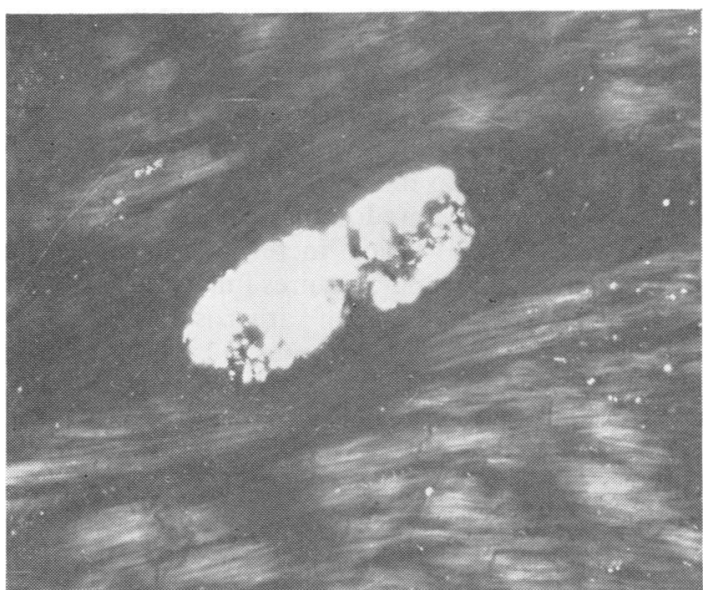

Fig 6 Coronary artery within left ventricular wall after 10 months of feeding on atherogenic diet $(A D-I)$ and $C S_{2}$ exposure. Crystalline cholesterol deposited in thickened arterial wall. (Polarised light; magn $\times 300$.)

turbances in the vascular walls manifested by a significant use in total cholesterol content. Within the composition of this fraction, a pronounced shift towards cholesterol esters was observed. Total cholesterol content in serum was also increased.

Introduction of atherogenic diets resulted in a rise in serum cholesterol content in control animal groups with a further rise in total and esterified cholesterol content in $\mathrm{CS}_{2}$-exposed rats. Statistically 
significant differences between $\mathrm{CS}_{2}$-exposed and control rats were obtained only when thiouracil was added to the atherogenic diet (AD-2). Therefore it seems that the combined effect of feeding with atherogenic diet and $\mathrm{CS}_{2}$ intoxication was not sufficient to raise serum cholesterol to the concentration that results in a pronounced accumulation of lipids in the aorta wall. Except in the region of the aortic valves, where advanced lipid infiltration was encountered, no major intimal lesions occurred in the aorta. Our findings differ in this aspect from those of other investigators who observed a more advanced atheromathosis after similar atherogenic diets. ${ }^{28-30}$

In our studies a major rise of cholesterol content in the aortic tissue of non-exposed control animals fed on diets AD-1 and AD-2 was repeatedly found throughout the duration of the experiment. The effect of $\mathrm{CS}_{2}$ intoxication follows the pattern of lipid changes within the aorta similar to those recorded in non-hypercholesterolaemic animals. It was observed that there was a moderate but significant increase in the content of total cholesterol. The increase in cholesterol was particularly pronounced within the esterified fraction. No significant changes in the content of vascular phospholipids were recorded. The above shift of the lipid spectrum bears a resemblance to the composition of lipids in the aorta wall shown at the plaque stage of experimental atherosclerosis $^{31-33}$ in contrast to the fatty streak stage, which is characterised by a predominant increase in free cholesterol with a minor increase of cholesterol esters. $^{34}$ This discrepancy requires further elucidation considering the absence of atherosclerotic gross lesions in our material.

A further confirmation of the biochemical findings is provided by the parallel histological examination of the heart. The morphological features of the coronary and endocardial lesions are consistent with data obtained in other laboratories for rats in similar atherogenic conditions. ${ }^{28} 2935$ As a result of long-term exposure to $\mathrm{CS}_{2}$, noticeable alterations in the small coronary arterial branches were observed. $\mathrm{CS}_{2}$ intensified arterial and endocardial lesions caused by atherogenic diets. These findings justify the conclusion that the endocardial and coronary arterial lesions are suitable experimental indicators of the vascular effects of $\mathrm{CS}_{2}$.

Results obtained in this study seem to confirm those clinical and laboratory data that indicate the promoting influence of $\mathrm{CS}_{2}$ on the development of atherosclerosis in general ${ }^{1-8}$ and on the progress of the coronary heart disease in particular..$^{9-11}$ On the basis of data on metabolic lipid disturbances, ${ }^{12-16} 19$ especially those proving the impairment of lipid metabolism in the aortic tissue, ${ }^{18} 2021$ the present findings indicate that altered cholesterol metabolism within the arterial wall play an important part in the vascular response of chronic $\mathrm{CS}_{2}$ intoxication.

We wish to express our appreciation to Miss Anna Cisek, Mrs Jadwiga Teodorczyk, and Mrs Zofia Rudnicka for their excellent technical help.

\section{References}

1 Attinger E. Chronische Schwefelkohlenstoffvergiftung unter dem "scheinbar ungewöhnlichem" Bilde einer schweren Gefässkrankheit. Schweiz Med Wochenschr $1948 ; 78: 667-9$

2 Vigliani EC, Pernis B. Klinische und experimentelle Untersuchungen über die durch Schwefelkohlenstoff bedigte Atherosclerose. Internationales Archiv fur Gewerbepathologie und Gewerbehygiene 1955;14:190-202.

${ }^{3}$ Rechenberg HK. Schwefelkohlenstoffvergiftung und das sulfocarbitixische vasculare Spätsyndrom. Internationales Archiv fur Gewerbepathologie und Gewerbehygiene 1957; $15: 487-530$.

4 Paterni I, Pusic G, Teodori S. Intossicazione lenta da $\mathrm{CS}_{2}$ e arteriosclerosi da dieta ipercolesterolica del coniglio. Folia Med 1958;41:705-9.

${ }^{5}$ Nofer J, Chojnowski J, Kawecka M, Kieć E, Wrońska T, Wyszomirska Z. Effect of occupational hazard to carbon disulphide on the pathogenesis of atherosclerosis. Med $\operatorname{Pr} 1961 ; 12: 101-18$.

6 Prerovska I, Vanecek R, Kubat K. Vliv sirouhliku na experimentalni arteriosklerosu u kraliku. Acta Univ Carol 1961 ;suppl 14:177-86.

${ }^{7}$ Prerovska I, Srbova J. The serum biochemistry of subjects exposed to carbon disulfide, in correlation to arteriosclerosis. Pracovni Lekarstvi 1963;15:25-30.

${ }^{8}$ Wrońska-Nofer T, Nofer J. Recherches expérimentales sur les troubles du métabolisme des lipides sous l'influence du sulfure de carbone. Toxicology of carbon disulphide. Amsterdam: Excerpta Medica Foundation, 1967:161-4.

${ }^{9}$ Tiller JR, Schilling RSF, Morris JN. Occupational toxic factor in mortality from coronary heart disease. $\mathrm{Br} \mathrm{Med} \mathrm{J}$ 1968 ;iv:407-11.

${ }^{10}$ Hernberg S, Partanen T, Nordman CH, Sumari P. Coronary heart disease among workers exposed to carbon disulphide. Br J Ind Med 1970;27:313-25.

11 Tolonen M. Chronic subclinical carbon disulfide poisoning. Work Environ Health 1974;11:154-65.

${ }^{12}$ Wrońska-Nofer $\mathrm{T}$. The incorporation of ${ }^{14} \mathrm{C}$-acetate into cholesterol in rats exposed to carbon disulphide. Biochem Pharmacol 1969;18:925-6.

${ }^{13}$ Wrońska-Nofer T. The influence of low doses of nicotinic acid upon the development of lipid disturbances in rats chronically exposed to carbon disulphide. Internationales Archiv fur Arbeitsmedizin 1972;29:285-90.

14 Wrońska-Nofer T. Disturbances of lipids metabolism in rats in dependence upon carbon disulphide concentrations in the air. Med Lav 1973;64:8-12.

15 Wrońska-Nofer T, Knobloch $\mathrm{K}$. The influence of variation of the daily rhythm of exposure upon the magnitude of biological effects: a comparison of $x$-ray irradiation and carbon disulphide intoxication. Bull Acad Pol Sci 1972; 20:813-9.

${ }^{16}$ Wrońska-Nofer T. Effect of carbon disulphide intoxication on fecal excretion of end products of cholesterol metabolism. Int Arch Occup Environ Health 1977;40: 261-5.

17 Górny R, Wrońska-Nofer T, Nofer J. L'influence d'heparine sur l'activite de la lipoproteine lipase dans les intoxications par le sulfure de carbone. Proc Int Congress 
Occup Health, Vienna 1966;359-62.

18 Wrońska-Nofer T, Gluszek B. Investigations on the lipolitic activity of the blood serum and the wall of the aorta in rats subjected to intoxication with carbon disulphide. Med Pr 1965;16:343-7.

19 Wrońska-Nofer T. Studies on in vivo incorporation of ${ }^{14} \mathrm{C}$-acetate and ${ }^{14} \mathrm{C}$-mevalonate into cholesterol in the liver of rat intoxicated with carbon disulphide. Internationales Archiv fur Arbeitsmedizin 1975;34:221-9.

${ }^{20}$ Szendzikowski S, Patelski J. Influence of CS intoxication on the lipolytic and esterolytic activity of the aorta of the rat. Patol Pol 1963;14,suppl 1:157-60.

${ }^{21}$ Wrońska-Nofer T, Parke M. Influence of carbon disulphide on metabolic processes in the aorta wall: study of the rate of cholesterol synthesis and the rate of influx of ${ }^{14} \mathrm{C}$-cholesterol from serum into the aorta wall. Int Arch Occup Environ Health 1978;42:63-8.

${ }^{22}$ Sperry WM, Webb M. A revision of the SchoenheimberSperry method for cholesterol determination. J Biol Chem 1959;187:97-105.

${ }^{23}$ Kaplan A, Lee VF. A micromethod for determination of serum triglycerides. Proc Soc Exp Biol Med 1965;118: 296-7.

${ }^{24}$ Usher DA. Estimation of phosphorus on paper chromatograms. J Chromatogr 1963;12:262-3.

${ }^{25}$ Mosinger F. Photometric adaptation of Dole's microdetermination of free fatty acids. J Lipid Res $1965 ; 6: 157-9$.

${ }^{26}$ Folch J, Less M, Sloane Stanley GH. A simple method for the isolation and purification of total lipids from animal tissue. J Biol Chem 1957;226:497-509.

${ }^{27}$ Babson AL, Shapiro PD, Phillips GE. A new assay for cholesterol and cholesterol esters in serum which is not affected by bilirubin. Clin Chim Acta 1962;7:800-4.

${ }^{28}$ Constantinides P. Experimental atherosclerosis. Amsterdam: Elsevier Publishing Co, 1965.

${ }^{29}$ Fillios LC, Andrus SB, Mann GV, Stare FJ. Experimental production of gross atherosclerosis in the rat. J Exp Med 1965;104:539-54.

${ }^{30}$ Scott GBD. Atherosclerosis, hyperlipaemia and hypocoagulability in the rat. Br J Exp Pathol 1964;45:102-9.

${ }^{31}$ Lofland HB, St Clair RW, Clarkson TB, Bullock BC, Lehner DM. Atherosclerosis in cebus monkeys. II Arterial metabolism. Exp Mol Pathol 1968;9:57-70.

${ }^{32}$ Smith EB. The influence of age and atherosclerosis on the chemistry of aortic intima. The lipids. J Atheroscler Res $1965 ; 5: 224-39$.

${ }^{33}$ Smith EB, Slater RS, Clin PK. The lipids in raised fatty and fibrous lesions in human aortas, a comparison of the changes at different stages of development. $J$ Atheroscler Res $1968 ; 8: 399-419$.

${ }^{34}$ Insull W, Bartsch GE. Cholesterol, triglyceride and phospholipid content of intima, media and atherosclerotic fatty streak in human thoracic aorta. J Clin Invest $1966 ; 45: 512-23$.

${ }^{35}$ Humphreys EM. Atherosclerosis in the coronary arteries of rats. J Atheroscler Res 1964;4:416-34. 